Revue bibliographique pour le domaine irano-aryen

\title{
Farshid Emami, "Coffeehouses, Urban Spaces, and the Formation of a Public Sphere in Safavid Isfahan"
}

Alexandra Van Puyvelde

\section{(2) OpenEdition Journals}

Electronic version

URL: http://journals.openedition.org/abstractairanica/43304

DOI: $10.4000 /$ abstractairanica.43304

ISBN: 1961-960X

ISSN: 1961-960X

Publisher:

CNRS (UMR 7528 Mondes iraniens et indiens), Éditions de l'IFRI

Electronic reference

Alexandra Van Puyvelde, "Farshid Emami, "Coffeehouses, Urban Spaces, and the Formation of a

Public Sphere in Safavid Isfahan" », Abstracta Iranica [Online], Volume 37-38-39 | 2018, document 26,

Online since 30 December 2018, connection on 27 September 2020. URL : http://

journals.openedition.org/abstractairanica/43304; DOI : https://doi.org/10.4000/abstractairanica. 43304

This text was automatically generated on 27 September 2020.

Tous droits réservés 


\title{
Farshid Emami, "Coffeehouses, Urban Spaces, and the Formation of a Public Sphere in Safavid Isfahan"
}

\author{
Alexandra Van Puyvelde
}

\section{REFERENCES}

Farshid Emami, "Coffeehouses, Urban Spaces, and the Formation of a Public Sphere in Safavid Isfahan", Muqarnas, XXXIII (2016), p. 177-220.

1 In this paper Farshid Emami examines the development of coffeehouses in Safavid Isfahan against the background of increased exchanges of goods in the early modern world.

2 He studies their architectural forms and integration in the newly built urban spaces and also their nature as new public meeting spaces. He relies on investigations of physical remnants of coffeehouses in situ, visual material (architectural drawings and $19^{\text {th }}$ century photographs) and textual sources (court chronicles, biographical dictionaries, literary works and western travel narratives).

3 The main focus lies on two series of coffeehouses, which were an integrated part of the building programs of Shah 'Abbas: firstly, two pairs of coffeehouses that were built in the northern part of the Chaharbagh promenade and secondly, a complex of six coffeehouses that was built at the northeastern side of the Maydan-i Naqsh-Jahan. The author paints a clear and vivid image of their architectural forms and constructions, the dynamic relation with their environment and the public and social life that took place in and around them.

4 In addition, Emami discusses coffeehouses in other neighborhoods of Isfahan, such as those of the Takhtgah neighborhood near the Old Maydan, and in provincial cities.

5 In discussing the social aspects, it appears that the new habit of drinking coffee and smoking tobacco in the coffeehouses of "new Isfahan" was mainly adopted by the elite 
of the Safavid society, whereas the coffeehouses in the "old city" had another character and housed a more varied audience.

6 In another section, the author pays attention to Isfahan's coffeehouses as places for literary gatherings, artists, artisans, poets and storytellers and as hubs for cultural exchange. Also the penetration of coffee-related imagery in Safavid literature and visual arts is discussed.

7 Finally Emami deals with the "subversive" character of Isfahan's coffeehouses. They are described as places where news was exchanged, politics were discussed and the government could be criticized. Shah 'Abbas, who visited the coffeehouses himself for entertainment and to represented himself as a visible ruler, started to take measures by ordering the presence of a mullah in the coffeehouses as a means of control.

8 With this contribution, Emami filled a gap in our knowledge of the architectural, urban and social features of Safavid Isfahan.

\section{AUTHORS}

\section{ALEXANDRA VAN PUYVELDE}

Royal Museums of Art \& History, Bruxelles 